Functions of Vitamins beyond Recommended Dietary Allowances 


\section{Bibliotheca \\ Nutritio et Dieta}

No. 55

Series Editors $\quad P$. Walter, Basel

J.C. Somogyi, Rüschlikon-Zürich

KARGER Pasel-Freiburg-Paris-London-New York- 


\title{
Functions of Vitamins beyond Recommended Dietary Allowances
}

\author{
Volume Editors \\ P. Walter, Basel \\ D. Hornig, Basel \\ U. Moser, Basel
}

34 figures and 26 tables, 2001 


\section{(n)}

Paul Walter

Biochemisches Institut

Vesalianum, Universität Basel

Vesalgasse 1

CH-4051 Basel (Switzerland)

\section{Dietrich Hornig}

F. Hoffmann-La Roche Ltd

Vitamins and Fine Chemicals Division

CH-4070 Basel (Switzerland)

\section{Ulrich K. Moser}

F. Hoffmann-La Roche Ltd

Vitamins and Fine Chemicals Division

CH-4070 Basel (Switzerland)

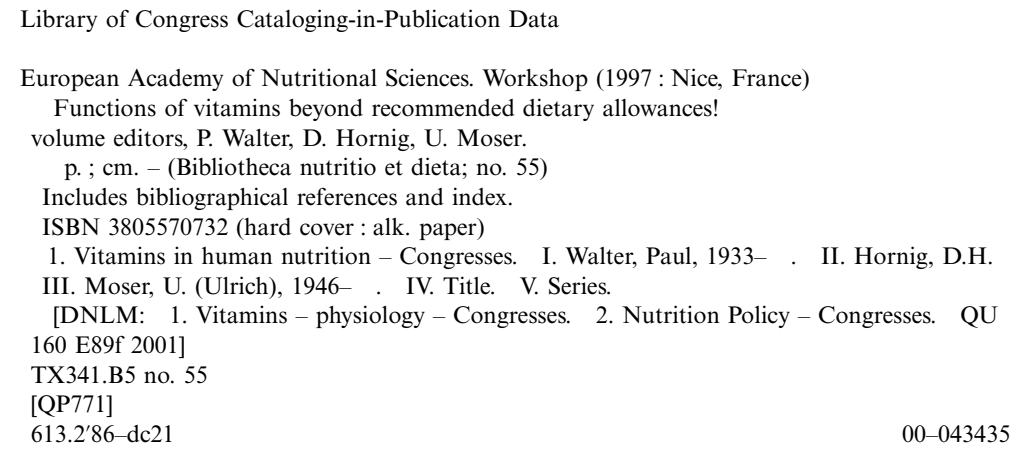

Bibliographic Indices. This publication is listed in bibliographic services, including Current Contents ${ }^{\circledR}$ and Index Medicus.

Drug Dosage. The authors and the publisher have exerted every effort to ensure that drug selection and dosage set forth in this text are in accord with current recommendations and practice at the time of publication. However, in view of ongoing research, changes in government regulations, and the constant flow of information relating to drug therapy and drug reactions, the reader is urged to check the package insert for each drug for any change in indications and dosage and for added warnings and precautions. This is particularly important when the recommended agent is a new and/or infrequently employed drug.

All rights reserved. No part of this publication may be translated into other languages, reproduced or utilized in any form or by any means electronic or mechanical, including photocopying, recording, microcopying, or by any information storage and retrieval system, without permission in writing from the publisher.

(C) Copyright 2001 by S. Karger AG, P.O. Box, CH-4009 Basel (Switzerland)

www.karger.com

Printed in Switzerland on acid-free paper by Reinhardt Druck, Basel

ISSN 0067-8198

ISBN 3-8055-7073-2 


\section{Contents}

IX Preface

Introduction and Objectives

1 A Conceptual Approach for Scientifically Based Guidelines Walter, P.; Hornig, D.; Moser, U. (Basel)

Recommendations for Vitamin Intake

4 Dietary Reference Intakes: A New Approach to Setting Nutrition Standards in the USA and Canada

Yates, A.A. (Washington, D.C.)

14 Recommendations for Vitamin Intake in the European Union and the Use of Reference Values in Existing and Future Community Legislation

Mathioudakis, B. (Brussels)

Evidence for Vitamin Functions beyond Recommended Dietary Allowances (RDAs)

Folic Acid, Vitamins $B_{6}$ and $B_{12}$

22 Folic Acid and Neural Tube Defects

Wald, N.J. (London)

34 Rationale for Risk Reduction of Cardiovascular Disease Using Homocysteine Concentration in Blood and Plasma as Biomarker: Support by Clinical Data

Pietrzik, K. (Bonn) 
42 Folate and Vitamin $B_{6}$ from Diet and Supplements in Relation to Risk of Coronary Heart Disease among Women

Rimm, E.B. (Boston, Mass.)

Antioxidant Vitamins

46 Antioxidant Vitamins: Evidence from Biomarkers in Humans Frei, B.; McCall, M.R. (Corvallis, Oreg.)

68 Synergistic Effects of Antioxidant Vitamins Truscott, T.G. (Keele)

80 Antioxidants and Chronic Disease: Evidence from Observational Epidemiology

Rimm, E.B.; Stampfer, M.J. (Boston, Mass.)

92 Evidence from Intervention Studies Biesalski, H.K. (Stuttgart)

Vitamins and Immunocompetence

135 Mechanisms of Vitamin-Mediated Anti-Inflammatory and Immunomodulatory Activity

Anderson, R. (Pretoria)

148 Vitamin E and Immune Response in the Aged Meydani, S.N.; Beharka, A.A. (Boston, Mass.)

Emerging Scientific Evidence

159 Vitamin $\mathrm{K}$ and Tissue Mineralization

Vermeer, C.; Thijssen, H.H.W.; Hamulyák, K. (Maastricht)

171 Behavioural and Mental Functions

Stăhelin, H.B. (Basel)

177 Vitamins and Regulation of Gene Expression

Azzi, A.; Aratri, E.; Boscoboinik, D.; Clément, S. (Bern); Özer, N. (Istanbul); Ricciarelli, R. (Genova); Spycher S.; Stocker A. (Bern)

Discussions in Working Groups

189 Folic Acid, Vitamins $B_{6}$ and $B_{12}$ : Relation to Homocysteine and Cardiovascular Disease

Kok, F.J. (Wageningen)

192 Evidence of Folic Acid and Folate in the Prevention of Neural Tube Defects

Scott, J.M. (Dublin)

196 Functions of Antioxidant Vitamins beyond RDAs

Diplock, A.T.'; van Poppel, G. (Zeist) 
200 Vitamins and Immunocompetence

Blumberg, J.B. (Boston, Mass.); Hughes, D.A. (Norwich)

206 Emerging Scientific Evidence. Vitamin K and Bone Metabolism: Effects of Vitamins on Behaviour and Cognition

Rambeck, W.A. (Munich); Stähelin, H.B. (Basel)

209 Author Index

210 Subject Index 


\section{(1) \\ Preface}

More and more has become known on new properties and functions of various nutrients in our food. Of particular interest are functions of single or combinations of vitamins which seem to be involved in the improvement of immune function and in the risk reduction of chronic diseases such as cardiovascular diseases, cancer, and also neurological disorders like Alzheimer disease. The about 50 experts of the workshop that was held under the auspices of the European Academy of Nutritional Sciences in October 1997 discussed the progress in this area in great detail. In the summary discussions, which are also part of this book, the questions were raised for which of the vitamins recommendations can be formulated or if the necessary evidence is still missing and what the estimated time scale for obtaining this knowledge will be. Since not only scientists but also the consumers are very much interested in this development especially concerning the reduction of the risk of chronic diseases it was also discussed how the consumer should be informed on the progress science is making.

This volume of 'Bibliotheca Nutritio et Dieta' is the last one both under my editorship and the present name. Starting with No. 56, the series will change its name to 'Forum of Nutrition', with Professor I. Elmadfa from Vienna as the new editor and myself as co-editor.

Paul Walter 